\title{
У Liikuntapaikkojen saavutettavuus fyysisesti inaktiivisilla miehillä Kymenlaakson taajamissa
}

Tutkimusten perusteella liikunnan harrastaminen on lisääntynyt viimeisten vuosikymmenien aikana, mutta silti osa väestöstä on fyysisesti inaktiivisia eli ei liiku riittävästi oman terveytensä ylläpitämiseksi. Liikunnan harrastamismäärät ovat yhteydessä sosioekonomisiin eroihin, sillä mitä korkeampi sosioekonominen asema, sitä todennäköisemmin liikkuu terveysliikuntasuositusten mukaisesti. Fyysisen inaktiivisuuden syyt selittyvät pääosin yksilölisillä tekijöillä, mutta myös asuinympäristön valinnan mahdollisuuksilla on todettu olevan merkitystä fyysiselle aktiivisuudelle. Tavoitteena tässä artikkelissa on tutkia fyysisesti inaktiivisten miesten väestöruuduttaista jakautumista kaupunkitilassa suhteessa liikuntapaikkojen saavutettavuuteen. Avaamme artikkelissa yleisesti liikunnallisen elämäntavan valinnan mahdollisuuksien paikkasidonnaisuutta ja liikuntapaikkojen saavutettavuuden vaihtelua sosioekonomisesti erilaisten asuinalueiden kesken. Artikkelin aineistot pohjautuvat kyselytutkimukseen, itseraportoituihin liikuntatietoihin ja Ruututietokannan sekä LIPAS-tietokannan paikkatietoaineistoihin. Näitä aineistoja käsitellään paikkatietoanalyyseihin, kuten saavutettavuuslaskennalla sekä spatiaalisella optimoinnilla. Tulokset osoittavat, että väestöruudun sosioekonominen tausta heijastuu miesten fyysiseen aktiivisuuteen. Fyysisesti inaktiiviset miehet kasautuvat pienituloisten vuokra-asujien väestöruutuihin, joissa heidän suhteellinen osuus on suurin, mutta joissa myös väestötiheys on suurinta. Epätasaisen jakautumisen vuoksi fyysisesti inaktiivisilla miehillä liikuntapaikkojen saavutettavuus on taajaan asutuilla alueilla heikompaa kuin koko väestöllä keskimäärin.

ASIASANAT: miehet, fyysinen inaktiivisuus, alueellinen erilaistuminen, liikuntapaikkojen saavutettavuus, paikkatietomenetelmät, Kymenlaakso

\section{OLLI LEHTONEN, MARJA-LEENA KAURONEN}

\section{JOHDANTO}

Paikallaan olon, istumisen ja fyysisen inaktiivisuuden käsitteet ovat nousseet esiin viime aikoina [1], kun istumisen ja paikallaan olon on havaittu lisäävän terveysriskejä, ja toisaalta kun, liikunnallisen elämäntyylin on korostettu parantavan mielenterveyttä, elämänlaatua, sosiaalista hyvinvointia ja koettua terveyttä [2,3]. Fyysisellä inaktiivisuudella tarkoitetaan fyysisesti passiivista tilaa, jossa henkilö ei liiku riittävästi oman terveytensä näkökulmasta [4]. Käsitteestä ei kuitenkaan ole yksimielisyyttä [5]. Liikunta-aktiivisuutta on tutkittu esimerkiksi päivittäisten askelten määrällä, jolloin fyysisesti inaktiiviseksi on määritelty alle 5000 askelta päivässä saavuttaneet henkilöt [6]. Terveyden parantamiseksi suositukset edellyttävät liikunnalta kuitenkin myös rasittavuutta ja toistoa. Terveysliikuntasuosituksien mukaan työikäisen aikuisen tulisi harrastaa reipasta liikuntaa 2 tuntia 30 minuuttia tai rasittavaa liikuntaa 1 tunti ja 15 minuuttia viikossa sekä lisäksi kaksi kertaa viikossa lihaskuntoa ja liikehallintaa kehittävää liikuntaa. [1,7] 
Tutkimusten perusteella liikunnan harrastaminen on lisääntynyt viimeisten vuosikymmenien aikana, mutta silti väestöstä noin 20 prosenttia on fyysisesti inaktiivisia [1,8]. Liikunnan harrastamismäärät ovat yhteydessä sosioekonomisiin eroihin, sillä hyvässä sosioekonomisessa asemassa (korkea koulutus ja tulotaso sekä hyvä ammattiasema) olevat liikkuvat vapaa-ajalla enemmän kuin matalammassa sosioekonomisessa asemassa olevat, mutta työnrasittavuudessa osat vaihtuvat toisin päin $[9,10]$. Tutkimustulokset viittaavat myös siihen, että mitä korkeampi sosioekonominen asema henkilöllä on, sitä todennäköisemmin hän liikkuu terveysliikuntasuositusten mukaisesti [11]. Huolestuttavaa on, että liikunnan sosioekonomiset erot ovat pysyneet Suomessa samankaltaisina jo yli 20 vuotta [12].

Asuinympäristö ennustaa väestön fyysistä aktiivisuutta [13]. Aiemmin tutkimuksissa on havaittu esimerkiksi liikunnallisen aktiivisuuden korreloivan positiivisesti asuinalueen sosioekonomisen taustan kanssa [14,15]. Näyttöä on myös alueen sosioekonomisen deprivaation kontekstuaalisesta merkityksestä terveysongelmien riskitekijänä $[13,16]$. Samoin on havaintoja siitä, että alhaisen sosioekonomisten taustan asuinalueilla on vähemmän avoimia tiloja ja ilmaisia vapaa-ajan liikuntamahdollisuuksia sekä heikompi saavutettavuus uimarannoille, golf- ja tenniskentille sekä ulkoilureiteille kuin korkeamman sosioekonomisen taustan asuinalueilla $[14,17]$. Nämä jälkimmäiset tutkimustulokset kuvastavat sosioekonomisten ryhmien eroja valinnan mahdollisuuksissa [18]. Suomessa on jossain määrin havaittu sosioekonomisia eroja liikuntalajien harrastamisessa [9,19]. Esimerkiksi korkeasti koulutetut suosivat kuntosaliharjoittelua, hiihtoa ja juoksua muita väestöryhmiä enemmän [19]. Kaupunkitilassa asuinalueiden sosioekonomista taustaa kuvataan alueellisella erilaistumisella, joka tarkoittaa tiivistetysti sosioekonomiselta taustaltaan samanlaisten ihmisten ajautumista asumaan toistensa läheisyyteen asuntokannan määrittämissä reunaehdoissa [20].

Liikunnallisen elämäntavan omaksumiseen vaikuttavat asuminen ja asuinympäristö, paikalliset valinnan mahdollisuudet, harrastustoiminta paikallistasolla sekä yhteisöllisessä toiminnassa yleisesti muodostuneet resurssit. Monipuoliset liikuntaympäristöt mahdollistavat asukkaiden liikkumista tarjoamalla vaihtoehtoja vapaa-ajan toimintoihin. Rakennettu ympäristö vaikuttaa mahdollisuuksien luomisen kautta kaupunkien sisällä olevien yhteisöjen sosiaalisiin prosesseihin, arvoihin ja normeihin ja yhteisö puolestaan yksilön elintapoihin. [21-24]. Edellä mainitut tekijät vaikuttavat yksilön valintoihin [24], mutta toisaalta, valintoihin voi vaikuttaa myös yksilön tai sosiaalisen ryhmän tiedostettu tai tiedostamaton elämäntapa, johon liittyvät aikaisempi tai nykyinen sosioekonominen asema osana yksilön sosiaalisesti tuotettua olemusta. Näin myös matalassa sosioekonomisessa asemassa olevilla on aina jonkinlaiset valinnan mahdollisuudet aktiviteeteissaan ja elämäntavoissaan. [24]

Hyvään asuinympäristöön liittyy sopivan asunnon lisäksi hyvä ilmanlaatu, matala melutaso, hyvä yleinen turvallisuus, esteettisyys, maisemaympäristö ja riittävän suuret ja yhtenäiset viheralueet [25]. Liikunta-aktiivisuuteen taas vaikuttavat harrastamiskustannukset, liikuntapaikkojen saavutettavuus, läheisyys, turvallisuus ja houkuttelevuus [26]. Liikunnan harrastaminen edellyttää säännöllisiä käyntejä liikuntapaikoissa, joten siksi pitkät etäisyydet tai niihin liittyvä matka-aika voivat luoda esteitä liikuntapalveluiden tehokkaalle käytölle. Heikossa sosioekonomisessa asemassa olevat korostavat liikuntaharrastusten kustannuksia, liikuntamahdollisuuksien huonoa saatavuutta ja toisaalta liikuntaympäristöjen turvattomuutta [27]. Harrastamiseen liittyvät kustannukset korostuvat, koska alhaisen sosioekonomisen taustan henkilöillä terveyteen käytettävissä olevat yksilötason resurssit ovat yleisesti hyvätuloisia pienemmät [28]. Myös liikuntapalvelujen tarjonta voi olla huonompaa heikommassa asemassa olevien asuinalueilla [27].

\section{TUTKIMUSTEHTÄVÄ}

Tässä tutkimuksessa tavoitteena on arvioida fyysisesti inaktiivisten miesten esiintyvyyttä kaupunkitilassa sekä tarkastella heidän sijoittumistaan suhteessa liikuntapaikkoihin. Yhdistämme fyysisesti inaktiivisten miesten lukumäärän arvioinnin väestöruutujen alueelliseen erilaistumiseen Kymenlaaksossa. Näin pyrimme avaamaan tässä tutkimuksessa liikunnallisen elämäntavan valinnan mahdollisuuksien paikkasidonnaisuutta ja liikuntapaikkojen saavutettavuuden vaihtelua sosioekonomisesti erilaistuneiden asuinalueiden kesken. Oletamme, että asuinalueiden alueellinen 
erilaistuminen yhdistyy alhaisempaan liikunnalliseen aktiivisuuteen osana sosiaalista ja kulttuurista eriytymistä ja liikuntamahdollisuuksien vähäisyyttä, kuten aiemmissa tutkimuksissa on viitattu $[14,17,27]$. Testaamme oletusta kysymällä ${ }^{1)} \mathrm{mi}$ ten fyysisen inaktiivisuuden esiintyvyys vaihtelee alueellisissa erilaistumisluokissa, ${ }^{2)}$ miten fyysinen inaktiivisuus jakautuu kaupunkitilaan ja ${ }^{3)}$ millaisia eroja fyysisesti inaktiivisilla miehillä on liikuntapaikkojen saavutettavuudessa.

Oletettujen valinnan mahdollisuuksien paikkasidonnaisuuden vuoksi kytkemme edellä esitetyt tutkimuskysymykset paikkatietoon, jota on aiemmin käytetty varsin vähän terveyserojen tutkimuksissa [29]. Paikkatieto tarkoittaa tietoa, joka sisältää sekä sijainti- että ominaisuustiedon. Se mahdollistaa uudenlaisen tarkastelun kaupunkien sisäisistä terveyseroista, koska oletettavasti väestöruudun sosioekonomisella taustalla voidaan ennustaa yksilöiden terveyskäyttäytymisen esiintyvyyttä väestöruuduissa. Usein alueelliset terveyserotutkimukset ovat Suomessa keskittyneet sairaanhoitopiirien tai kuntatyyppien tilastolliseen vertailuun, mikä ei paljasta tarkkoja terveyseroja esimerkiksi kuntien sisällä eikä siten mahdollista esimerkiksi fyysisen inaktiivisuuden esiintyvyyden huomioimista liikuntapaikkojen suunnittelussa. Toisin sanoen kuntatilastot eivät ole riittävän tarkkoja paikkatietoaineistoja, jotta liikuntapaikat pystyttäisiin niiden perusteella allokoimaan optimaalisesti kuntien asuinalueille siten, että liikuntapaikat sijoittuisivat mahdollisimman lähelle käyttäjiä. Terveyseroja koskevan tarkan paikkatiedon puuttumisen vuoksi liikuntapalveluja on suunniteltu kunnissa niin, että ne ovat yhtäläisesti koko väestön saavutettavissa [30]. Tällöin suunnittelussa ei huomioida sitä, että sosioekonomisten terveyserojen myötä liikuntaan käytettävät resurssit eroavat asuinalueiden asukkaiden kesken ja siksi pienetkin saavutettavuuserot asuinalueiden välillä voivat olla fyysisen aktiivisuuden näkökulmasta merkittäviä.

Liikuntapaikkojen fyysistä saavutettavuutta tutkitaan tässä artikkelissa geoinformatiikan menetelmillä, jotka perustuvat paikkatiedon ominaisuuksien analysoitiin. Paikkatietoa on esimerkiksi koordinaatti- tai osoitetieto liikuntapaikan sijainnista, jos siihen liittyy myös ominaisuustieto siitä, millainen liikuntapaikka on kysymyksessä. Geoinformatiikan analyysien tuottama lisäarvo tiedolle syntyy sen sitomisesta paikkaan, mikä mahdollistaa esimerkiksi tiestön avulla liikuntapaikan saavutettavuuden tarkastelun. Saavutettavuus on määre, joka kuvaa esimerkiksi, minkä ajan tai etäisyyden kuluessa tietty liikuntapaikka voidaan tavoittaa [31]. Geoinformatiikan menetelmiä on hyödynnetty laajalti yleistä hyvinvointia edistävien virkistysja liikunta-alueiden suunnittelussa [32]. Myös liikuntapaikkojen suunnittelussa nämä menetelmät ovat hyödyllisiä, sillä liikuntapaikkojen on kannattavaa sijaita mahdollisimman lähellä käyttäjäkuntaa, jolloin palveluja voidaan käyttää mahdollisimman vaivattomasti [33]. Tällöin palvelujen suunnittelussa huomioidaan käyttäjien fyysinen etäisyys tai matka-aika siten, että palvelut sijaitsevat mahdollisimman lähellä suurta potentiaalista käyttäjäjoukkoa. Yleisesti palvelujen heikon saavutettavuuden on todettu vähentävän niiden käyttöä [34-36].

\section{TUTKIMUSAINEISTOT}

Tässä tutkimuksessa keskitymme kymenlaaksolaisiin miehiin, koska he muodostavat terveyskäyttäytymisen riskiryhmän alueellaan. Kymenlaaksolaiset miehet kokevat terveytensä heikommaksi kuin suomalaiset miehet keskimäärin ja lisäksi heidän elinajanodotteensa poikkeaa valtakunnallisesta keskiarvosta enemmän kuin naisten. Tutkimusalueella sosioekonomiset erot ovat myös muita alueita vahvemmin yhteydessä terveyteen, sillä matala koulutustaso ja miessukupuoli ovat Kymenlaaksossa lisänneet riskiä ennenaikaisiin kuolemiin. [37] Koulutustaso on alueella yhteydessä myös vapaa-ajan liikunnan harrastamiseen, sillä matalan koulutustason miehistä 28 prosenttia ei harrasta vapaa-ajan liikuntaa, kun vastaava osuus korkeasti koulutetuilla on 19 prosenttia [38].

\section{I KYSELYAINEISTO MIESTEN LIIKUNNAN HARRASTAMISESTA}

Miesten liikuntakäyttäytymistä tutkittiin 1001 satunnaisesti valitulla puhelinhaastattelulla, jotka kohdistuivat 18-64-vuotiaisiin Kymenlaaksossa pysyvästi asuviin miehiin. Otos vakioitiin miesten asuinkuntien ja iän suhteen, joten alueen kunnat ja ikäluokat ovat aineistossa edustettuna suhteessa väkilukuun ja ikärakenteeseen. Puhelinhaastattelut toteuttti heinäkuussa 2014 TNS Gallup. Alueellinen erilaistumisluokitus yhdistettiin haastateltujen miesten kyselylomakkeen tietoihin kysymällä heidän asuinpaikkansa osoite, jonka 
perusteella miehet geokoodattiin eli paikannettiin koordinaatistoon ja lopuksi liitettiin alueelliseen erilaistumisluokitukseen.

Puhelinhaastatteluissa miesten liikunnan harrastamista kysyttiin tiedustelemalla, kuinka usein miehet harrastavat vapaa-ajan liikuntaa vähintään puoli tuntia niin, että he ainakin lievästi hengästyvät ja hikoilevat (vastausvaihtoehdot: 1 = päivittäin, 2=4-6 kertaa viikossa, $3=3$ kertaa viikossa, $4=2$ kertaa viikossa, $5=$ kerran viikossa, $6=2-3$ kertaa kuukaudessa, $7=$ muutaman kerran vuodessa tai harvemmin, $8=$ en voi vamman tai sairauden vuoksi harrastaa liikuntaa). Fyysisesti inaktiiviseksi määritettiin kysymyksen perusteella mies, joka harrastaa liikuntaa harvemmin kuin yhden kerran viikossa. Tällä harrastavuusrajalla keskitytään niihin miehiin, jotka ovat tosiasiassa fyysisesti inaktiivisia, koska subjektiivissa kysymyksissä usein yliarvioidaan omaa liikuntakäyttäytymistä. Kysymys pohjautuu Mini-Suomi tutkimukseen vuosilta 1977-1980, minkä tarkoituksena oli luoda kansallisen terveysseurantajärjestelmän perusta ja josta myöhemmin kehitettiin Terveys 2000, suomalaisiin kohdistuva terveys- ja toimintakykytutkimus [39]. Kysymystä on käytetty myös Suomalaisen aikuisväestön terveyskäyttäytyminen ja terveys -tutkimuksissa [40].

Tiedostamme, että liikuntakäyttäytymistä arvioiva kysymys on likimääräinen, koska se ei tuo esiin tarkasti liikunnan rasittavuutta, toistuvuutta eikä kestoa [10], mutta lyhyissä puhelinhaastatteluissa ei ollut mahdollista kysyä liikunnan harrastamista tarkasti. Tuloksia tulkittaessa on pidettävä mielessä se, että tässä tutkimuksessa on selvitetty liikuntaa ja kuntoilua vain harrastuksena. Määritelmämme fyysiselle inaktiivisuudelle ei siis pidä sisällään esimerkiksi työliikuntaa, joka jossain ammattiryhmissä on valtaosa kokonaisliikunnasta ja sisältää myös terveysliikunnan kriteerit täyttäviä osia. Keskittymistä vapaa-ajan liikuntaa voidaan tosin perustella sillä, että vapaa-ajan liikunta on yleistynyt mutta työmatkaliikunta sekä työhön sisältyvä fyysisen aktiivisuus ovat vähentyneet kolmen viime vuosikymmenen kuluessa ja niiden yhteen laskettu merkitys on nykyään pienempi kuin vapaa-ajan liikunnan [1]. Tutkimuksissa käytetyn kaltaisia liikuntamittareita on heikkouksista huolimatta pidetty toimivina erottelemaan väestötasolla inaktiiviset henkilöt aktiivisista henkilöistä [1].

\subsection{LIIKUNTAPAIKKOJA KOSKEVAT PAIKKATIETOAINEISTOT}

Saavutettavuusanalyysejä varten Kymenlaakson liikuntapaikat poimittiin Jyväskylän yliopiston liikuntatieteellisen tiedekunnan hallinnoimasta Lipas-paikkatietokannasta. Tämä tietokanta sisältää kattavasti tietoja liikuntapaikoista, virkistysalueista, ulkoilureiteistä ja liikuntatoimen taloudesta, ja sen tietosisällön tuottavat pääasiallisesti liikuntatoimen asiantuntijat kunnissa. Liikuntapaikoista analyyseissä keskitytään suosituimpiin, joita vuonna 2009 olivat kevyen liikenteen väylät, pyöräilytiet, lenkkeilytiet ja ulkoilureitit. Sisäliikuntatiloista kymmenen suosituimman liikuntapaikan listalla olivat kuntosali, uimahalli ja koulun liikuntasali. [41] Näistä suosituimmissa liikuntapaikoista Lipas-tietokannasta poimittiin analyyseihin ulkoliikuntakentät (Lipas-luokituksessa jalkapallokenttä, lähiliikuntapaikka, luistelukenttä), sisäliikuntahallit (liikuntasali ja liikuntahalli), kuntosalit (kuntosali ja kuntokeskus) sekä uimahallit. Lisäksi Lipas-tietokannasta haettiin kuntoreitit. Lipas-tietokannan ajankohtaisuutta varmistettiin tarkistamalla kunnilta niitä koskevien tietojen ajantasaisuus. Kuntosalien osalta tarkastus suoritettiin Fonectan hakupalvelussa. Lipas-paikkatietokantaa täydennettiin Maanmittauslaitoksen tuottamasta maastotietokannasta poimimalla tästä tietokannasta kävelyja pyörätiet sekä polut, jotka sisältävät kaikki alle 2 metriä leveät kuntoradat. Reittitietoja lukuun ottamatta liikuntapaikka-aineisto on tallennettu pistemuotoiseksi. Reittitiedot muutettiin viivamuodosta pistemäisiksi käyttäen hyväksi QGIS-ohjelman mmqgis-lisäosalla. Näin tehtiin, koska ainoastaan pistemäistä paikkatietoa voitiin hyödyntää saavutettavuuslaskennoissa.

\subsection{FYYSISESTI INAKTIIVISET MIEHET ALUEELLISISSA ERILAISTUMISLUOKISSA}

Väestön sosioekonomista taustaa kuvaavaa alueellista erilaistumista hyödynnetään tässä tutkimuksessa arvioitaessa fyysisesti inaktiivisten miesten lukumäärï väestöruuduissa. Arviossa nojaudutaan useissa tutkimuksissa havaittuihin sosioekonomisiin terveyseroihin, joita on havaittu niin yksilö $[9,10,42,43]$ kuin myös aluetasolla $[13,15]$. Kymenlaakson alueellinen erilaistumisluokitus muodostettiin vuoden 2012 ruututietokannasta ruutukoolla $250 \mathrm{~m} * 250 \mathrm{~m}$ (liite 1). Ruututietokannan sisältö ei soveltunut tutkimukseen sellaisenaan, vaan sen sisältämiä muuttujia 
muokattiin ja yhdisteltiin uusiksi muuttujiksi. Yleisin muuttujille tehty muunnos oli muuntaa absoluuttiset arvot suhteellisiksi arvoiksi, jotta ruutujen väliset erot esimerkiksi väestömäärässä eivät määrittäisi pelkästään saatavia tuloksia. Tästä syystä vuoksi ennen ryhmittelyanalyysiä muuttujat myös standardisoitiin. Ryhmien lukumäärän valinnassa hyödynnettiin ryhmittelyn stabiiliutta mittaavia indeksejä [44], jotka vähentävät tutkijan subjektiivista vaikutusta ryhmien lukumäärän päättämisessä. Calinskin ja Harabaszin sekä Ratkowskyn ja Lancen indeksien perusteella jaoimme väestöruudut neljään luokkaan: vanhempi väestö, pienituloiset vuokraasujat, keskituloiset ja hyvätuloiset omistusasujat (kuva 1). Luokkien sosioekonomiset taustat vastaavat Kymenlaakson aikaisempaa alueellista erilaistumisluokitusta [20].

Ryhmittelyanalyysissä muodostui kaksi korkeampaa sosioekonomista taustaa kuvaavaa erilaistumisluokkaa (liite 1). Toinen näistä erilaistumisluokista kuvastaa hyvätuloisuutta ja siihen kuuluu tutkimusalueella 207 väestöruutua ja noin 10 prosenttia analyysissä mukana olleiden väestöruutujen 41064 miehestä. Tyypillisesti tähän luokkaan kuuluvissa väestöruuduissa asuntokanta koostuu isoista omistusasunnoista, asukkailla on korkea koulutustaso sekä korkeat keskitulot ja ruuduissa on matala työttömyysaste. Toiselle eli keskituloisten erilaistumisluokalle on väestöruuduissa tunnusomaista keskimääräiset keskitulot, keskisuuret asunnot ja omistusasuntojen suuri osuus asuntokannassa. Tähän luokkaan kuuluvilla 750 väestöruudulla asuu noin 41 prosenttia väestöruutujen miehistä. Ryhmittelyanalyysissä muodostui myös kaksi alhaisempaa sosioekonomista taustaa kuvaavaa erilaistumisluokkaa (liite 1; kuva 1). Näistä ensimmäinen kuvaa vanhemman väestön väestöruutuja, kos$\mathrm{ka}$ erilaistumisluokkaan kuuluvilla ruuduilla on suhteellisesti muita luokkia enemmän eläkeläistalouksia. Tämän erilaistumisluokan väestöruuduissa asui 30 prosenttia kaikkien ruutujen miehistä. Toinen alhaisemman sosioekonomisen taustan erilaistumisluokka, pienituloiset vuokraasujat, eroaa muista luokista korkean työttömyyden, yleisen pienituloisuuden, alhaisen koulutustason sekä vuokra-asuntojen yleisyyden suhteen. Tutkimusalueella tähän luokkaan kuuluu 151 väestöruutua, joissa asui 19 prosenttia väestöruutujen miehistä.
Puhelinhaastatteluja tehtäessä kyselyaineiston keruuta ei voitu osittaa luokituksen perusteella. Siksi kyselyyn vastanneiden ja erilaistumisluokkien väestöruuduissa asuvien miesten lukumäärien osuudet erilaistumisluokittain eivät täysin vastaa toisiaan (taulukko 1, liite 1 ). Suhteellisesti eniten aineistossa painottuvat hyvätuloisten väestöruuduilla asuvat vastaajat, sillä heitä on kyselyaineistossa 21 prosenttia vastaajista, mutta väestöruutujen miehistä hyvätuloisten väestöruuduissa asuu noin 10 prosenttia miehistä. Näin yliedustus on 11 prosenttia. Vastaavasti aliedustettuja vastaajaryhmiä ovat keskituloisten ja pienituloisten väestöruuduissa asuvat vastaajat. Näissä ryhmissä aliedustus on 9 ja 7 prosenttia.

Sosioekonomisen taustan suhteen kyselyaineisto näyttää edustavalta, sillä taustaa kuvaavat muuttujat yhtyvät alueellisen erilaistumisluokituksen sosioekonomisiin taustoihin (taulukko 1). Hyvätuloisten asuinalueilla asuvat kyselyyn vastanneet miehet ovat muita korkeammin koulutettuja ja heillä on myös erilaistumisluokituksen mukaisesti muita korkeammat tulot (taulukko 1). Vastaavasti keskituloisten asuinalueilla asuvilla miehillä koulutus- sekä tulotaso ovat alemmat kuin hyvätuloisten asuinalueiden vastaajilla, mutta korkeammat kuin vanhemman väestön tai pienituloisten asuinalueilla asuvilla vastaajilla (taulukko 1). Erilaistumisluokitukseen verrattuna vanhemman väestön asuinalueilla on vähemmän eläkeläisiä, koska kyselytutkimuksessa haastatellut miehet olivat iältään 18-64-vuotiaita. Vanhemman väestön asuinalueilla asuvat miehet eroavat kuitenkin muista luokista tulotasossa sekä työvoiman ulkopuolella olevien osuudessa (taulukko 1). Erilaistumisluokituksen mukaisesti pienituloisten asuinalueilla asuvat vastaajat eroavat selkeästi muista luokista koulutustasossa, työvoiman ulkopuolella olevien osuudessa sekä tulotasossa (taulukko 1).

Tarkemmin kyselyaineiston sosioekonomista taustaa suhteessa erilaistumisluokitukseen pystytään vertailemaan koulutustasolla ja työttömyydellä. Hyvätuloisten väestöruuduissa on korkeasti koulutetut aliedustettuina (erotus 11 prosenttiyksikköä) samoin kuin pienituloisten väestöruuduissa työttömät (erotus 13 prosenttiyksikköä). Vanhemman väestön väestöruuduissa korkeasti koulutetut ovat puolestaan yliedustet- 

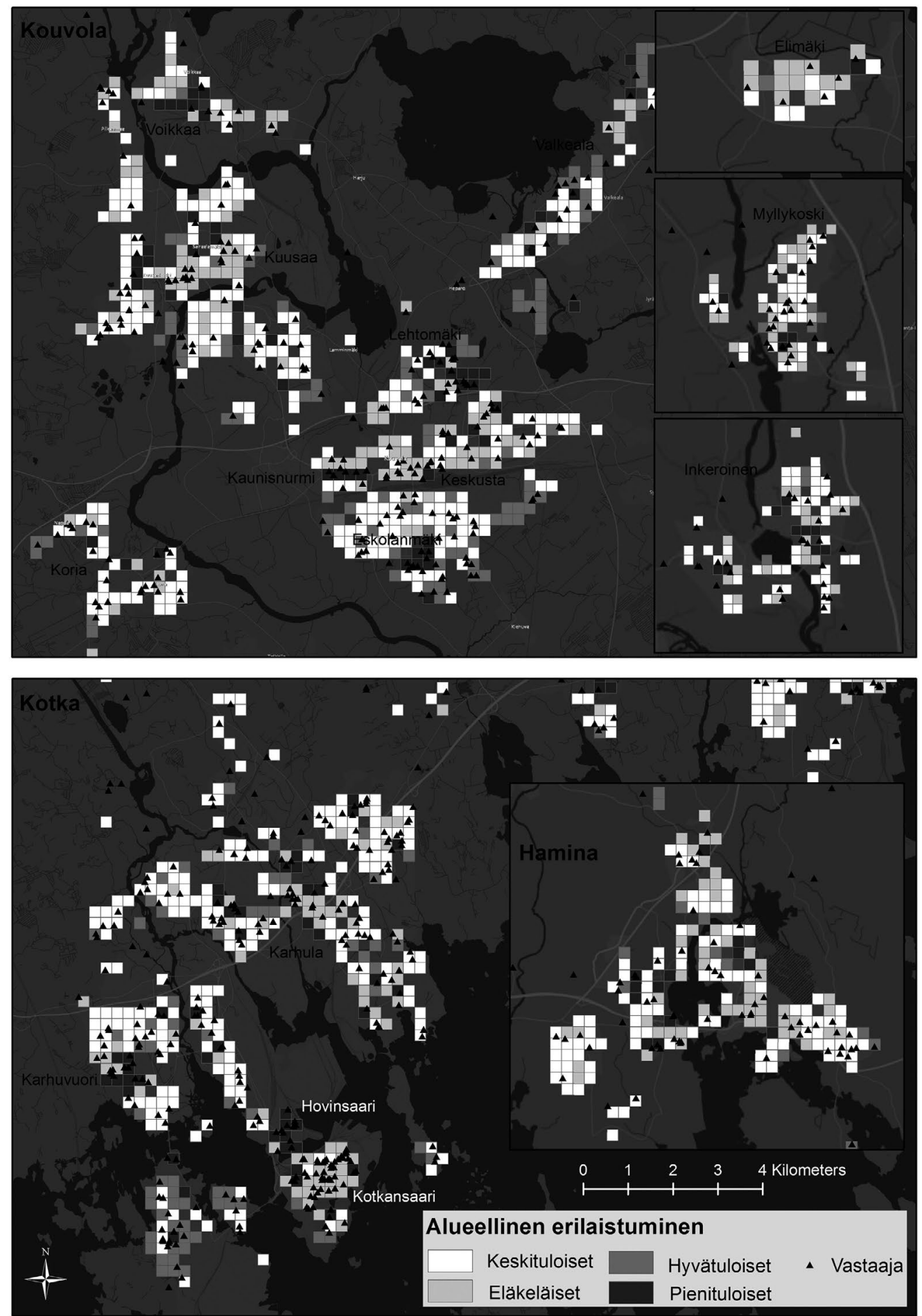

Kuva 1. Alueellinen erilaistuminen Kymenlaaksossa. 
Taulukko 1. Tietoja vastaajien sosioekonomisesta taustasta erilaistumisluokittain. Alueellinen erilaistuminen kuvastaa väestöruudussa asuvan väestön sosioekonomista asemaa.

\begin{tabular}{lcccc}
\hline muuttuja & vanhempi väestö & keskituloiset & pienituloiset & hyvätuloiset \\
\hline vastaajia $(\mathrm{n})$ & 238 & 217 & 80 & 143 \\
\hline vastaajia $(\%)$ & 35,1 & 32,0 & 11,8 & 21,1 \\
\hline keski-ikä & 44,1 & 40,8 & 45,5 & 40,5 \\
\hline perusasteen suorittaneet $(\%)$ & 12,6 & 12,9 & 13,8 & 6,3 \\
\hline $\begin{array}{l}\text { korkeakoulutus } \\
\text { (alempi + ylempi) }(\%)\end{array}$ & 13,9 & 14,3 & 11,8 & 16,8 \\
\hline kokopäivätyössä $(\%)$ & 56 & 71 & 48 & 71 \\
\hline työtön $(\%)$ & 14,3 & 8,8 & 13,8 & 4,9 \\
\hline eläkkeellä $(\%)$ & 14,7 & 11,1 & 18,8 & 16,8 \\
\hline tulot alle $20000 €(\%)$ & 23,8 & 21,7 & 33,8 & 4,9 \\
\hline tulot yli $50000 €(\%)$ & 10,9 & 19,8 & 11,3 & 27,3 \\
\hline
\end{tabular}

tuina suhteessa erilaistumisluokkien väestöruutuihin (erotus 4 prosenttiyksikköä). Näiden perusteella sosioekonomiset erot voivat ilmetä kyselyaineistossa heikompana kuin todellisuudessa.

\section{TILASTOLLISET MENETELMÄT}

\section{I SPATIAALINEN AUTOKORRELAATIO}

Fyysisesti inaktiivisten miesten sijoittumista väestöruuduissa analysoidaan spatiaalisella autokorrelaatiolla, joka voi olla positiivista tai negatiivista tavallisen korrelaation tavoin. Positiivinen spatiaalinen autokorrelaatio tarkoittaa samankaltaisten havaintoarvojen sijoittumista toistensa läheisyyteen [45]. Positiivinen autokorrelaatio kuvaa siten trendiä, jossa fyysisesti inaktiiviset miehet kasautuvat paikallisesti. Negatiivinen autokorrelaatio puolestaan kuvaa tilannetta, jossa läheiset väestöruudut eroavat toisistaan huomattavasti enemmän kuin satunnaisuus antaisi olettaa [45]. Spatiaalista autokorrelaatiota voidaan visualisoida paikallisen spatiaalisen autokorrelaation indeksillä (LISA, Local indicator of spatial autocorrelation) [46], joka kuvaa tässä tutkimuksessa fyysisesti inaktiivisten miesten muodostamia kasautumia kaupunkien sisällä. Tilastollisesti satunnaisesta spatiaalisesta jakautumisesta poikkeavat havaintoyksiköt jaetaan LISA-indeksin arvojen perusteella neljään ryhmään. Tässä tutkimuksessa huomio kiinnittyy korkea-korkea-ryhmään, jonka väestöruudut saavat ympäröivien väestöruutujen kanssa korkeita positiivisia indek- siarvoja. Tämä tarkoittaa fyysisesti inaktiivisten miesten kasautumista näihin väestöruutuihin.

\subsection{LIIKUNTAPAIKKOJEN SAAVUTETTAVUUSANALYYSIT}

Saavutettavuusanalyyseillä tarkastellaan tässä tutkimuksessa liikuntapaikkojen saavutettavuutta väestöruuduittain. Saavutettavuuden laskenta edellyttää, että tiedetään palvelujen sijoittuminen, niiden käyttäjien sijainti sekä verkosto, jota pitkin saavutettavuus lasketaan. Saavutettavuutta kuvataan usein etäisyydellä, ajalla tai matkakustannuksilla [47]. Tässä tutkimuksessa käytämme saavutettavuuden arvioinnissa fyysistä etäisyyttä. Paikkatietomenetelmien hyödyntäminen terveyspalveluissa on keskittynyt saavutettavuuteen ja palveluverkon kehittämiseen erikoissairaanhoidossa ja päivystävien sairaaloiden sijainnin optimointiin [33]. Saavutettavuudessa paneudumme ensisijaisesti liikuntapaikkojen fyysiseen saavutettavuuteen. Jos liikuntapaikat sijaitsevat fyysisesti kaukana tai ovat muuten vaikeasti saavutettavissa, saatetaan palvelun käyttöä lykätä tai se saatetaan jättää kokonaan käyttämättä [34]. Siten voidaan olettaa, että liikuntapaikkojen fyysinen saavutettavuus vaikuttaa suoraan siihen, millaisia valinnan mahdollisuuksia liikunnan harrastamiseen asuinympäristössä on tarjolla. Liikuntapaikkojen taloudellinen ja tiedollinen osa-alue saavutettavuudesta jäävät tämän tutkimuksen ulkopuolelle.

Liikuntapaikkojen saavutettavuuden laskennassa käytetään yleistä saavutettavuusindikaattoria eli suhteellista saavutettavuutta [48]. Tämä indikaattori perustuu ajatukseen siitä, että 
kohteen houkuttelevuus kasvaa kohteen koon kasvaessa (väestöruudun väkiluku $\mathrm{V}_{\mathrm{i}}$ ) ja vähenee etäisyyden kasvaessa $\left(\mathrm{e}_{\mathrm{ij}}\right)$. Yhtälömuodossa suhteellisen saavutettavuuden indikaattori $\left(\mathrm{S}_{\mathrm{i}}\right)$ voidaan kirjoittaa seuraavasti:

$$
S_{i}=\sum_{j=1}^{n} \frac{V_{j}}{E_{i j}^{\alpha}},
$$

jossa merkintä $\alpha$ tarkoittaa etäisyyskitkan parametriä. Parametrin arvona käytetään yleisesti käytettyä arvoa 1 [48]. Suhteellisen saavutettavuuden lisäksi saavutettavuutta arvioitiin yksinkertaisesti lyhimpänä etäisyytenä lähimpään liikuntapaikkaan. Siten tarkastelussa oletetaan, että liikuntapaikat ovat ominaisuuksiltaan samanlaisia. Liikuntapaikkojen saavutettavuusanalyysit on laskettu ArcGIS-paikkatieto-ohjelman Network Analyst -työkalulla. Käytettävissä oleva saavutettavuustieto perustuu Digiroad-tieverkkoon vuodelta 2014 [49]. Saavutettavuuden laskennassa tehtiin olettamus, että liikuntapaikkoja käytettäisiin asuinpaikasta käsin.

\subsection{SPATIAALINEN OPTIMOINTI}

Spatiaalisella optimoinnilla tutkitaan nykyisten liikuntapaikkojen sijainteja suhteessa spatiaalisesti optimoituihin sijainteihin. Liikuntapaikkojen optimaaliset sijaintipaikat määritetään lyhimpään etäisyyteen pohjautuen fyysisesti inaktiivisille miehille ja koko väestölle. Optimointi fyysisesti inaktiivisten miesten osalta antaa mahdollisuuden verrata nykyisten liikuntapaikkojen sijaintia suhteessa tämän erityisryhmän tarpeisiin. Koko väestön osalta optimointi mahdollistaa liikuntapaikkojen nykyisten sijaintien vertailtavuuden suhteessa koko väestöön. Näiden optimointien avulla voidaan laskea lyhimpään etäisyyteen pohjautuvat saavutettavuuserot nykyisten ja optimaalisesti sijoitettujen liikuntapaikkojen välille.

Liikuntapaikkojen sijainnin optimointi pohjautuu ArcGIS-paikkatieto-ohjelmiston Network Analyst -sovelluksella laskettavaan tieverkostoon perustuvaan reitinoptimointiin. Spatiaalisessa optimoinnissa liikuntapaikat voivat mahdollisesti sijaita missä päin tahansa kaupunkialueella. Tätä varten alueelle luotiin $100 \mathrm{~m} * 100 \mathrm{~m}$ ruudukko, jonka keskipisteet ovat mahdollisia sijainteja liikuntapaikoille. Painotus suoritetaan optimoinnissa fyysisesti inaktiivisten miesten lukumäärän sekä koko väestön lukumäärän perusteella. Lii- kuntapaikkojen lukumääränä käytetään niiden nykyistä lukumäärää eikä liikuntapaikkojen lukumäärää siten optimoinnissa lisätä tai vähennetä, vaikka tämäkin olisi mahdollista. Spatiaalinen optimointi tehdään minimize impedance -menetelmällä, joka pohjautuu p-mediaani ongelmaan.

\section{TULOKSET}

\section{I FYYSISESTI INAKTIIVISTEN MIESTEN SIJOITTUMINEN KYMENLAAKSOSSA}

Fyysisesti inaktiiviset miehet eivät jakaudu kaupunkitilassa tasaisesti, sillä heidän esiintyvyys on riippuvaista erilaistumisluokituksesta $\left(\mathrm{Khi}^{2}\right.$ 14,301, p-arvo 0,006). Korkein esiintyvyys on pienituloisten vuokra-asujien väestöruuduissa, joissa asuvista vastaajista 22,5 prosenttia luokittuu kyselyssä fyysisesti inaktiivisiksi (taulukko 2). Tämä osuus on miltei 3 kertaa suurempi kuin hyvätuloisten väestöruuduissa, joissa fyysisen inaktiivisuuden esiintyminen on alhaisinta (taulukko 2). Koko aineistossa harvemmin kuin kerran liikuntaa ilmoitti harrastavansa 14,4 prosenttia miehistä.

Erilaistumisluokkien väliset erot fyysisessä inaktiivisuudessa kasvavat, kun esiintyvyyden lisäksi huomioidaan myös luokkien väliset erot väestötiheydessä (taulukko 2). Arvio fyysisesti inaktiivisten miesten lukumääristä erilaistumisluokkien väestöruuduissa tehdään kertomalla jokaisessa väestöruudussa fyysisesti inaktiivisten miesten osuus 18-64-vuotiaiden miesten lukumäärällä. Näin arvioituna fyysisesti inaktiivisia miehiä on Kymenlaaksossa 8339 (95\% luottamusväli: 7077-9546). Yksittäisissä väestöruuduissa fyysisesti inaktiivisia miehiä on lukumäärällisesti eniten pienituloisten vuokra-asujien erilaistumisluokassa. Tässä erilaistumisluokassa asuu keskimäärin jokaisessa väestöruudussa 11,6 fyysisesti inaktiivista miestä. Hyvätuloisten väestöruuduissa miehiä on keskimäärin lukumäärällisesti vähiten, sillä väestöruuduissa asuu arvion mukaan 1,6 fyysisesti inaktiivista miestä. Niinpä pienituloisten vuokra-asujien väestöruuduissa on 6,5 kertaa enemmän fyysisesti inaktiivisia miehiä kuin hyvätuloisten väestöruuduissa. Väestötiheyden erot johtavatkin yhdessä sosioekonomisten terveyserojen kanssa fyysisesti inaktiivisten miesten paikallisiin kasautumisiin pienituloisten vuokra-asujien väestöruutuihin. 
Taulukko 2. Tietoja fyysisesti inaktiivisten miesten lukumääristä erilaistumisluokittain. Fyysisesti inaktiivinen mies harrastaa liikuntaa harvemmin kuin yhden kerran viikossa.

\begin{tabular}{lcccc}
\hline muuttuja & vanhempi väestö & keskituloiset & pienituloiset & hyvätuloiset \\
\hline $\begin{array}{l}\text { fyysisesti inaktiivisia miehiä (\%) } \\
\text { (suluissa 95\% luottamusväli) }\end{array}$ & $\begin{array}{c}14,7 \\
(10,2-19,2)\end{array}$ & $\begin{array}{c}12,4 \\
(8,0-16,8)\end{array}$ & $\begin{array}{c}22,5 \\
(13,5-31,6)\end{array}$ & $\begin{array}{c}7,7 \\
(3,3-12,0)\end{array}$ \\
\hline fyysisesti inaktiivisia miehï̈ (n) & 1703 & 2084 & 1741 & 331 \\
\hline $\begin{array}{l}\text { fyysisesti inaktiivisia miehiä/ } \\
\text { väestöruutu }\end{array}$ & 4,7 & 2,8 & 11,6 & 1,6 \\
\hline $\begin{array}{l}\text { fyysisesti inaktiivisten miesten osuus } \\
\text { koko maakunnan miehistä (\%) }\end{array}$ & 20,5 & 25,1 & 21,0 & 4,0 \\
\hline
\end{tabular}

Visuaalisessa tarkastelussa fyysisesti inaktiiviset miehet muodostavat Kymenlaaksossa selkeitä kasautumia asuinalueille, joissa on useita pienituloisten vuokra-asujien väestöruutuja vierekkäin (kuva 2). Nämä kasautumat sijoittuvat esimerkiksi Kouvolassa Eskolanmäkeen, Lehtomäkeen ja Kaunisnurmeen sekä Kotkassa Karhuvuoreen, Hovinsaareen ja Kotkansaareen (kuva 2). Kasautumien asuinalueet ovat kerrostalovaltaisia ja ne on pääsääntöisesti rakennettu 1970-luvulla kaupunkikeskustojen ulkopuolelle. Spatiaalisen autokorrelaation indeksi tukee visuaalista tulkintaa fyysisesti inaktiivisten miesten kasautumisesta (Moran I 0,285, p-arvo <0,001; (etäisyyssäde $1000 \mathrm{~m}$ ); Moran I 0,252, p-arvo $<0,001$ (etäisyyssäde $2000 \mathrm{~m}$ ); Moran I 0,185, p-arvo <0,001 (etäisyyssäde $3000 \mathrm{~m}$ )). Spatiaalinen autokorrelaatio on seurausta voimakkaasta alueellisesta erilaistumista ja siihen liittyvistä väestötiheyseroista.

Kuvaan 2 on rasteroitu niin sanotut korkeakorkea-väestöruudut. Nämä väestöruudut kuvaavat fyysisesti inaktiivisten miesten paikallisia spatiaalisia kasautumia, joissa inaktiivisuuden esiintyvyys on lukumäärällisesti poikkeuksellisen suurta. Kasautumisen myötä korkea-korkeaväestöruuduissa fyysisesti inaktiivisia miehiä on paljon niin rasteroiduissa väestöruuduissa että myös niiden lähiympäristöissä. Määritetyissä 104 korkea-korkea-väestöruuduissa asuu 2110 fyysisesti inaktiivista miestä eli noin 25 prosenttia arvioidusta fyysisesti inaktiivisten miesten lukumäärästä Kymenlaaksossa. Keskimäärin kasautumiin kuuluvissa väestöruuduissa on fyysisesti inaktiivisia miehiä 20, joka on selvästi enemmän kuin esimerkiksi pienituloisten vuokraasujien väestöruuduissa (ks. taulukko 2).

\subsection{LIIKUNTAPAIKKOJEN SIJAINTI SUHTEESSA FYYSISESTI INAKTIIVISIIN MIEHIIN}

Taulukkoon 3 on kerätty tietoja liikuntapaikkojen saavutettavuudesta väestöruuduittain. Liikuntapaikkojen kesken on suuria eroja niiden saavutettavuudessa (taulukko 3). Väestöruuduista keskimäärin parhaiten saavutettavimpia liikuntapaikkoja ovat liikuntakentät ja sisäliikuntahallit, koska niiden lukumäärä on alueella korkea. Alueellisen erilaistumisluokkien kesken on myös eroja liikuntapaikkojen saavutettavuudessa (taulukko 3).

Liikuntapaikkojen sijoittumista suhteessa fyysisesti inaktiivisiin miehiin ja koko väestöön tarkastellaan seuraavaksi spatiaalisella optimoinnilla. Analyysin valikoitiin ne liikuntapaikat, joissa liikunnan harrastaminen vaatii sisätiloja tai ovat muuten paikkariippuvaisia. Taulukossa 4 verrataan liikuntapaikkojen nykyisiä sijainteja spatiaalisesti optimoituihin sijainteihin. Saavutettavuuseroa kuvataan nykyisten ja optimoitujen sijaintien keskimääräisten lyhimpien etäisyyksien erotuksena. Lasketut saavutettavuuserot eri optimiratkaisujen välillä antavat tietoa siitä, miten liikuntapaikkojen suunnittelu suhteutuu fyysisesti inaktiivisten miesten sijoittumiseen kaupunkitilassa. Laskennasta nähdään, että nykyiset liikuntapaikkojen sijainnit poikkeavat merkittävästi niiden optimisijainneista, jos liikuntapaikat suunniteltaisiin fyysisesti inaktiivisten miesten lähtökohdista (taulukko 4). Kotkassa suhteellinen saavutettavuusero on pienempi kuin Kouvolassa, mutta sielläkin ero on pienimmillään kuntosaleissa lähes 60 prosenttia. Kouvolassa kaikkien liikuntapaikkojen saavutettavuus fyysisesti inaktiivisilla miehillä parantuisi optimisijainneissa yli 120 prosentilla. Kummas- 

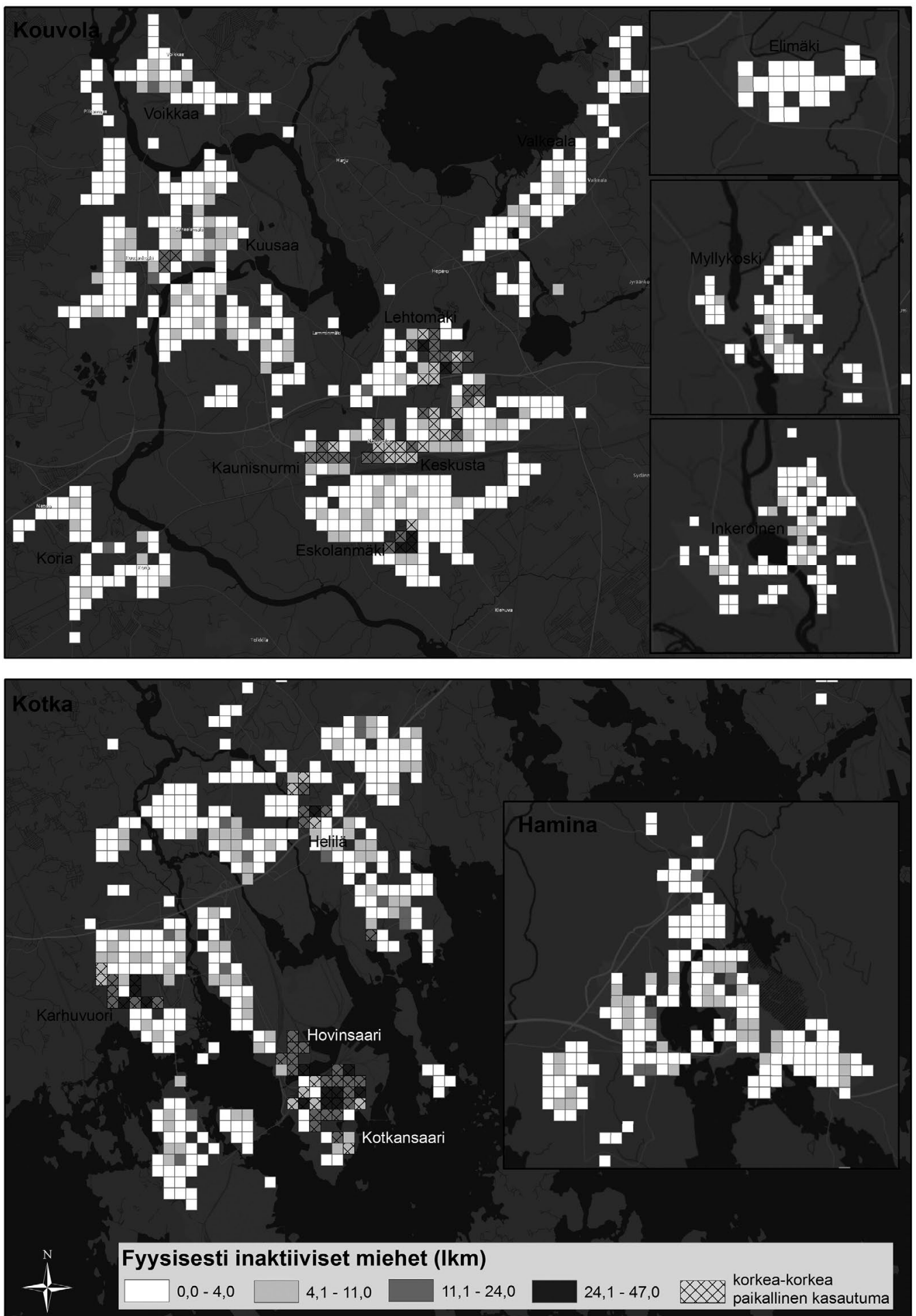

Kuva 2. Arvio fyysisesti inaktiivisten miesten lukumääristä väestöruuduttain Kymenlaakson suurimmissa kaupungeissa. Fyysisesti inaktiivinen mies harrastaa liikuntaa harvemmin kuin yhden kerran viikossa. Paikallisen spatiaalisen autokorrelaation laskennassa käytettiin etäisyyteen pohjautuvaa painomatriisia, jossa säteenä oli 1000 metriä. 
Taulukko 3. Väestöruutujen keskimääräinen lyhin tiestöä pitkin laskettu etäisyys $(\mathrm{km})$ ja suhteellinen saavutettavuus liikuntapaikkoihin erilaistumisluokittain. Suhteellinen saavutettavuus laskettu luvussa 3.2.2 esitetyllä kaavalla.

\begin{tabular}{|c|c|c|c|c|c|c|c|c|}
\hline \multirow[t]{2}{*}{ muuttuja } & \multirow[t]{2}{*}{ mittari } & \multicolumn{4}{|c|}{ erilaistumisluokka } & \multirow{2}{*}{$\begin{array}{l}\text { väestö- } \\
\text { ruutujen } \\
\text { keski- } \\
\text { arvo }\end{array}$} & \multicolumn{2}{|c|}{ varianssi-analyysi } \\
\hline & & $\begin{array}{l}\text { vanhem- } \\
\text { pi väestö }\end{array}$ & $\begin{array}{l}\text { keski- } \\
\text { tuloiset }\end{array}$ & $\begin{array}{l}\text { pieni- } \\
\text { tuloiset } \\
\text { vuokra- } \\
\text { asujat }\end{array}$ & $\begin{array}{l}\text { hyvä- } \\
\text { tuloiset }\end{array}$ & & $\mathrm{F}$ & p-arvo \\
\hline \multirow{2}{*}{$\begin{array}{l}\text { liikunta- } \\
\text { kenttä } \\
(\mathrm{n}=218)\end{array}$} & lyhin etäisyys & 0,940 & 0,939 & 0,901 & 0,941 & 0,936 & 0,594 & 0,619 \\
\hline & $\begin{array}{l}\text { suhteellinen } \\
\text { saavutettavuus }\end{array}$ & 0,173 & 0,085 & 0,191 & 0,077 & 0,117 & 42,970 & $<0,001$ \\
\hline \multirow{2}{*}{$\begin{array}{l}\text { sisälii- } \\
\text { kunta- } \\
\text { halli } \\
(\mathrm{n}=132) \\
\end{array}$} & lyhin etäisyys & 0,997 & 1,146 & 0,991 & 1,227 & 1,105 & 3,233 & 0,021 \\
\hline & $\begin{array}{l}\text { suhteellinen } \\
\text { saavutettavuus }\end{array}$ & 0,161 & 0,052 & 0,125 & 0,036 & 0,084 & 45,051 & $<0,001$ \\
\hline \multirow{2}{*}{$\begin{array}{l}\text { kuntosali } \\
(\mathrm{n}=49)\end{array}$} & lyhin etäisyys & 3,028 & 2,653 & 2,466 & 2,373 & 2,686 & 8,696 & $<0,001$ \\
\hline & $\begin{array}{l}\text { suhteellinen } \\
\text { saavutettavuus }\end{array}$ & 0,111 & 0,034 & 0,080 & 0,026 & 0,056 & 41,513 & $<0,001$ \\
\hline \multirow{2}{*}{$\begin{array}{l}\text { uimahalli } \\
(\mathrm{n}=12)\end{array}$} & lyhin etäisyys & 6,088 & 4,202 & 5,778 & 4,231 & 4,834 & 15,910 & $<0,001$ \\
\hline & $\begin{array}{l}\text { suhteellinen } \\
\text { saavutettavuus }\end{array}$ & 0,019 & 0,011 & 0,024 & 0,010 & 0,014 & 43,590 & $<0,001$ \\
\hline kävelytie & lyhin etäisyys & 3,030 & 0,888 & 2,856 & 0,745 & 1,595 & 21,391 & $<0,001$ \\
\hline $\begin{array}{l}\text { kunto- } \\
\text { reitti }\end{array}$ & lyhin etäisyys & 1,231 & 1,498 & 1,527 & 1,569 & 1,446 & 3,085 & 0,026 \\
\hline
\end{tabular}

sakin kaupungissa tulokset viittaavat siihen, että fyysisesti inaktiivisten miesten sijoittuminen kaupunkien sisällä ei ole ohjannut liikuntapaikkojen sijoittumisen suunnittelua.

Fyysisesti inaktiivisten miesten huomioimattomuuteen liikuntapaikkojen suunnittelussa viittaa myös se, että fyysisesti inaktiivisilla on keskimäärin suurempi etäisyys liikuntapaikkoihin, jos liikuntapaikat suunniteltaisiin koko väestön suhteen (taulukko 4). Tällöin erot optimiratkaisujen välillä ovat melko pieniä ja vaihtelevat noin 3-22 prosentin väliltä, mutta fyysisesti inaktiivisilla miehillä olisi liikuntapaikkojen saavutettavuus keskimäärin kuitenkin koko väestöä heikompi. Erot johtuvat siitä, että fyysisesti inaktiiviset miehet eivät jakaudu kaupunkitilaan tasaisesti muuhun väestöön suhteutettuna, vaan kuten edellisessä luvussa on osoitettu, he kasautuvat osaan väestöruutuja ja asuinalueita. Mielenkiintoisesti molemmissa kaupungeissa suhteellisesti saavutettavuuserot fyysisesti inaktiivisilla miehillä ovat suurimmat niissä liikuntapaikoissa, joita on lukumäärällisesti eniten eli liikuntakentissä ja sisäliikuntahalleissa (taulukko 4).

Spatiaalinen optimointi paljastaa, että myös koko väestön osalta liikuntapaikat ovat molemmissa kaupungeissa nykyään selvästi optimirat- kaisuun verrattuna heikommin saavutettavissa (taulukko 4). Havainto voi johtua väestörakenteen muutoksista, mutta myös siitä, että liikuntapaikkojen suunnittelussa ei ole pystytty huomioimaan optimaalisesti koko väestöä. Suurin ero on Kouvolassa sisäliikuntahalleissa ja kuntosaleissa, joissa molemmissa ero optimiratkaisuun on yli 100 prosenttia (taulukko 4). Kotkassa suurin erotus voidaan havaita liikuntakenttien kategoriassa, sillä nykyinen liikuntakenttien keskimääräinen etäisyys poikkeaa yli 150 prosenttia spatiaalisesti optimoidusta ratkaisusta (taulukko 4).

Alueellisissa erilaistumisluokissa saavutettavuuserot optimisijainteihin korostuvat erityisesti pienituloisten vuokra-asujien väestöruuduilla (taulukko 5). Kouvolassa pienituloisten vuokraasujien väestöruuduissa nykyiset liikuntapaikkojen sijainnit poikkeavat eniten optimoiduista koko väestöä tai fyysisesti inaktiivisia miehiä koskevista optimaalisista ratkaisuista. Muissa ryhmissä optimisijaintien välillä ei ole suuria eroja, ja verrattuna pienituloisten vuokra-asujien väestöruutuihin niissä on myös nykytilanteen ero optimisijainteihin selvästi pienempi (taulukko 5). Itse asiassa näissä muissa ryhmissä fyysisesti inaktiivisten miesten lukumäärän perusteella optimoitu liikuntapaikkojen sijoittuminen heikentää 
Taulukko 4. Nykyisten liikuntapaikkojen saavutettavuuden erotus spatiaalisesti optimoitujen liikuntapaikkojen saavutettavuuteen (\%). Saavutettavuusero laskettu keskimääräisen lyhimmän etäisyyden perusteella nykyisten liikuntapaikkojen ja spatiaalisesti optimoitujen liikuntapaikkojen välillä. Spatiaalisissa optimoinneissa liikuntapaikat sijoitettu niin, että fyysisesti inaktiivisten miesten ja koko väestön etäisyys liikuntapaikkoihin minimoituu.

\begin{tabular}{|c|c|c|c|}
\hline liikuntapaikan & \multicolumn{3}{|l|}{ Kouvola } \\
\hline \multirow[t]{2}{*}{ saavutettavuus } & \multicolumn{2}{|c|}{$\begin{array}{l}\text { fyysisesti inaktiivisten miesten perusteella } \\
\text { optimoitujen liikuntapaikkojen } \\
\text { saavutettavuusero }\end{array}$} & \multirow{2}{*}{$\begin{array}{l}\text { koko väestön } \\
\text { optimiratkaisun } \\
\text { saavutettavuusero } \\
\text { nykyisiin } \\
\text { liikuntapaikkojen } \\
\text { sijainteihin }\end{array}$} \\
\hline & $\begin{array}{l}\text { nykyisiin } \\
\text { liikuntapaikkoihin }\end{array}$ & $\begin{array}{l}\text { koko väestön perusteella } \\
\text { optimoituihin } \\
\text { liikuntapaikkoihin }\end{array}$ & \\
\hline liikuntakenttä & 231,4 & 21,8 & 12,3 \\
\hline sisäliikuntahalli & 160,2 & 9,9 & 132,6 \\
\hline kuntosali & 124,4 & 3,1 & 107,2 \\
\hline \multirow{3}{*}{$\begin{array}{l}\text { liikuntapaikan } \\
\text { saavutettavuus }\end{array}$} & \multicolumn{3}{|l|}{ Kotka } \\
\hline & \multicolumn{2}{|c|}{$\begin{array}{l}\text { fyysisesti inaktiivisten miesten perusteella } \\
\text { optimoitujen liikuntapaikkojen } \\
\text { saavutettavuusero }\end{array}$} & \multirow{2}{*}{$\begin{array}{l}\text { koko väestön } \\
\text { optimiratkaisun } \\
\text { saavutettavuusero } \\
\text { nykyisiin } \\
\text { liikuntapaikkojen } \\
\text { sijainteihin }\end{array}$} \\
\hline & nykyisiin liikuntapaikkoihin & $\begin{array}{l}\text { koko väestön perusteella } \\
\text { optimoituihin } \\
\text { liikuntapaikkoihin }\end{array}$ & \\
\hline liikuntakenttä & 191,6 & 15,3 & 165,1 \\
\hline sisäliikuntahalli & 78,4 & 7,9 & 71,5 \\
\hline kuntosali & 58,2 & 3,0 & 47,8 \\
\hline
\end{tabular}

Taulukko 5. Nykyisten liikuntapaikkojen saavutettavuuden erotus spatiaalisesti optimoitujen liikuntapaikkojen saavutettavuuteen erilaistumisluokittain (\%), Saavutettavuusero laskettu keskimääräisen lyhimmän etäisyyden perusteella nykyisten liikuntapaikkojen ja spatiaalisesti optimoitujen liikuntapaikkojen välillä.

\begin{tabular}{|c|c|c|c|c|}
\hline \multirow{3}{*}{$\begin{array}{l}\text { liikuntapaikan } \\
\text { saavutettavuus }\end{array}$} & \multicolumn{2}{|l|}{ vanhempi väestö } & \multicolumn{2}{|l|}{ keskituloiset } \\
\hline & \multicolumn{2}{|c|}{$\begin{array}{l}\text { fyysisesti inaktiivisten miesten } \\
\text { perusteella optimoitujen } \\
\text { liikuntapaikkojen saavutettavuusero }\end{array}$} & \multicolumn{2}{|c|}{$\begin{array}{l}\text { fyysisesti inaktiivisten miesten } \\
\text { perusteella optimoitujen liikuntapaikkojen } \\
\text { saavutettavuusero }\end{array}$} \\
\hline & $\begin{array}{l}\text { nykyisiin } \\
\text { liikuntapaikkoihin }\end{array}$ & $\begin{array}{l}\text { koko väestön } \\
\text { perusteella } \\
\text { optimoituihin } \\
\text { liikuntapaikkoihin }\end{array}$ & $\begin{array}{l}\text { nykyisiin } \\
\text { liikuntapaikkoihin }\end{array}$ & $\begin{array}{l}\text { koko väestön } \\
\text { perusteella } \\
\text { optimoituihin } \\
\text { liikuntapaikkoihin }\end{array}$ \\
\hline liikuntakenttä & 174,9 & 3,2 & 136,3 & 13,9 \\
\hline sisäliikuntahalli & 106,2 & $-3,9$ & 107,0 & $-5,8$ \\
\hline kuntosali & 90,3 & $-7,9$ & 104,1 & $-0,1$ \\
\hline \multirow{3}{*}{$\begin{array}{l}\text { liikuntapaikan } \\
\text { saavutettavuus }\end{array}$} & \multicolumn{2}{|c|}{ pienituloiset vuokra-asujat } & \multicolumn{2}{|l|}{ hyvätuloiset } \\
\hline & \multicolumn{2}{|c|}{$\begin{array}{l}\text { fyysisesti inaktiivisten miesten } \\
\text { perusteella optimoitujen } \\
\text { liikuntapaikkojen saavutettavuusero }\end{array}$} & \multicolumn{2}{|c|}{$\begin{array}{l}\text { fyysisesti inaktiivisten miesten } \\
\text { perusteella optimoitujen liikuntapaikkojen } \\
\text { saavutettavuusero }\end{array}$} \\
\hline & $\begin{array}{l}\text { nykyisiin } \\
\text { liikuntapaikkoihin }\end{array}$ & $\begin{array}{l}\text { koko väestön } \\
\text { perusteella } \\
\text { optimoituihin } \\
\text { liikuntapaikkoihin }\end{array}$ & $\begin{array}{l}\text { nykyisiin } \\
\text { liikuntapaikkoihin }\end{array}$ & $\begin{array}{l}\text { koko väestön } \\
\text { perusteella } \\
\text { optimoituihin } \\
\text { liikuntapaikkoihin }\end{array}$ \\
\hline liikuntakenttä & 305,6 & 32,5 & 142,1 & 7,4 \\
\hline sisäliikuntahalli & 327,1 & 45,8 & 89,6 & $-13,1$ \\
\hline kuntosali & 189,8 & 10,6 & 81,1 & $-4,6$ \\
\hline
\end{tabular}




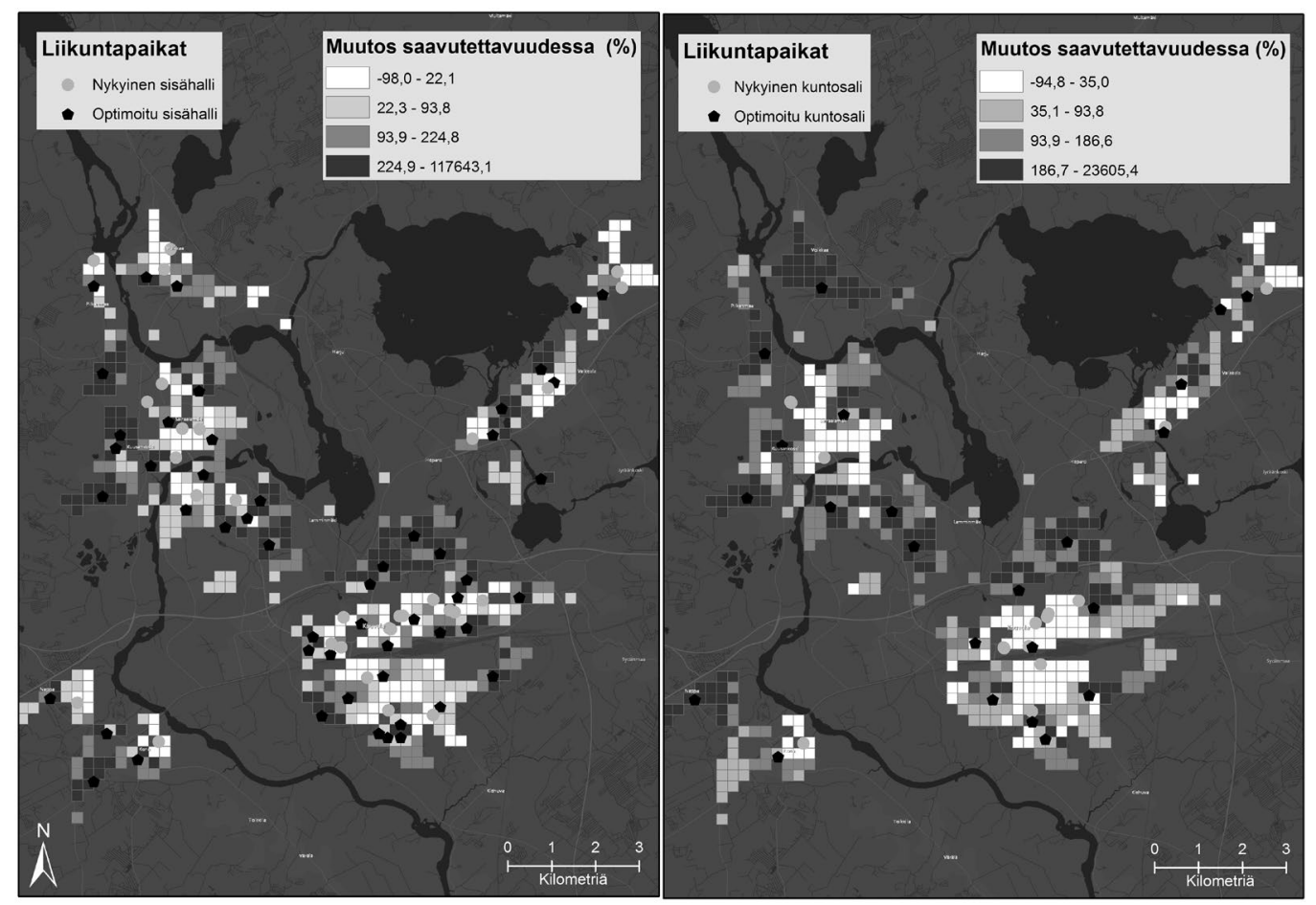

Kuva 3. Sisähallien ja kuntosalien nykyiset ja fyysisesti inaktiivisten miesten sijoittumisen perusteella optimoidut sijainnit Kouvolassa sekä näiden saavutettavuuden suhteellinen erotus (\%). Positiiviset arvot erotuksessa viittaavat saavutettavuuden parantumiseen. Fyysisesti inaktiivinen mies harrastaa liikuntaa harvemmin kuin yhden kerran viikossa.

väestöruutujen saavutettavuutta suhteessa koko väestöön. Siksi erotus sisäliikuntahallin ja kuntosalin saavutettavuudessa näkyy taulukossa 5 negatiivisena. Tulkinnallisesti tämä kuvastaa fyysisesti inaktiivisten miesten kasautumista pienituloisten vuokra-asujien väestöruutuihin, kuten aiemmin on todettu ja kuvastaa epäsuhtaa liikuntapalveluiden saavutettavuuden $\mathrm{ja}$ inaktiivisten miesten välillä.

Kuvassa 3 on visualisoitu Kouvolan keskustaajamassa sisäliikuntahallien ja kuntosalien sijainnit sekä fyysisesti inaktiivisten miesten perusteella spatiaalisesti optimoidut sijaintipaikat näille liikuntapaikoille. Kuvassa 3 esitetään myös väestöruuduittain suhteellinen muutos lähimmän liikuntapaikan saavutettavuudessa. Kartan perusteella optimoidut ratkaisut eroavat paikallisesti paljonkin liikuntapaikkojen nykyisistä sijainneista. Yleisesti liikuntapaikat näyttävät fyysisesti inaktiivisten miesten näkökulmasta sijoittuvan liiaksi keskusalueille (kuva 3).

\section{POHDINTA JA JOHTOPÄÄTÖKSET}

Perinteisesti alueelliset terveys- ja hyvinvointitarkastelut ovat perustuneet hallinnollisiin alueyksiköihin, kuten kuntiin, mutta tässä tutkimuksessa asuinalue ja sen sosioekonomista taustaa kuvaava erilaistumisluokitus määritettiin $250 \mathrm{~m}$ x $250 \mathrm{~m}$ väestöruudun tarkkuudella. Väestöruudun sosioekonomisen tausta heijastuu tuloksissa miesten liikunnan harrastusmääriin. Yleisesti liikuntaa harrastivat eniten hyvätuloisten väestöruuduilla asuvat miehet, kun taas vähiten liikuntaa harrastivat pienituloisten vuokra-asujien väestöruuduilla asuvat miehet. Tuloksissa arvioimme otoksen perusteella, että pienituloisten vuokra-asujien jokaisessa väestöruudussa on 6,5 kertaa enemmän fyysisesti inaktiivisia miehiä kuin esimerkiksi hyvätuloisten väestöruuduissa. Spatiaalisissa kasautumissa fyysisesti inaktiivisia miehiä oli arviolta noin 13 kertaa enemmän kuin hyvätuloisten väestöruuduissa. Havaitut suuret erot kuvastavat fyysisesti inaktiivisten miesten sijoittuvan kau- 
punkitilaan epätasaisesti ja sosioekonomisten erojen kuvautuvan myös väestöruuduissa. Havainnot väestöruutujen sosioekonomisen taustan merkityksestä liikuntakäyttäytymiseen tukevat väestöruututasolla aikaisempaa tutkimusta, jossa yksilötasolla alhainen sosioekonominen asema (koulutuksella, tuloilla tai ammattiasemalla mitattuna) on ollut yhteydessä vähäiseen liikuntaaktiivisuuteen [9]. Yksilötason tutkimusten mukaisesti myös väestöruutujen sosioekonominen tausta ennustaa miesten liikuntakäyttäytymistä.

Fyysisen inaktiivisuuden kasautuminen ehdottaa tämän huomioimista myös asuinympäristön suunnittelussa sekä liikuntapalvelujen kohdentamisessa. Tämä havainto tuloksissa näkyy siinä, että alueellisen erilaistumisen myötä liikuntapaikkojen sijoittuminen tutkimusalueen kaupungeissa ei vastaa optimaalisesti fyysisen inaktiivisuuden esiintyvyyteen väestöruuduissa. Spatiaaliset optimoinnit osoittivat liikuntapaikkojen suunnittelun tapahtuneen koko väestön lähtökohdista, joten liikuntapaikkojen saavutettavuutta ei ohjannut fyysisesti inaktiivisten miesten sijoittuminen kaupunkitilassa. Siten suunnittelussa ei ole tunnistettu sosioekonomisia eroja liikunnan harrastamisessa, mikä voi olla yhtenä osasyynä havaitulle eroille fyysisessä aktiivisuudessa. Tätä selittää tutkimustiedon vähyys väestöruutujen sosioekonomisen taustan yhteydestä liikuntakäyttäytymiseen, monialaisen yhteistyön puute kaavoitusprosesseissa, terveyskyselyjen ja tilastoaineistojen mahdolliset puuttumiset sekä kaupungin eri toimialojen yhteistyön puute. Merkitystä voi olla myös sillä, että liikuntapaikkojen elinkaari on pitkä, joten niiden sijainti ei mukaudu väestörakenteen muutoksiin.

Asuinalueiden erilaistuminen yhdistyy alhaisempaan fyysiseen aktiivisuuteen osana sosioekonomista eriytymistä. Liikuntapaikkojen heikko saavutettavuus näkyy lisääntyvänä fyysisenä inaktiivisuutena. Alueellisen erilaistumisen myötä asuinalueilla on erilaiset resurssit liikunnan harrastamiseen. Esimerkiksi alhaisen sosioekonomisen taustan asuinalueilla etäisyydet liikuntapaikkoihin ovat alhaisten tulojen vuoksi merkityksellisempiä kuin suurituloisilla, jotka liikkuvat huolimatta liikunnan aiheuttamista matkoista ja kuluista [28]. Toisaalta fyysisesti inaktiivisten miesten heikompi saavutettavuus liikuntapaikkoihin kuvastaa asuinympäristön vähäisiä liikunnanharrastamismahdollisuuksia. Liikunnallisen elämäntavan valinnan mahdollisuudet ovatkin tulosten perusteella paikkasidonnaisia. Myös aikaisemmissa tutkimuksissa liikuntapaikkojen heikko saavutettavuus ja kunto ovat osaltaan heijastuneet liikunnan harrastamiseen $[14,17,50]$ ja siten selittäneet havaittuja eroja, vaikka asuinympäristön merkitys liikuntakäyttäytymisen selittäjänä on pienenä. Aikaisemmassa tutkimuksessa asuinympäristöä kuvaavat muuttujat selittävät kymenlaaksoslaisten miesten fyysisestä aktiivisuudesta 4-10 prosenttia riippuen kaltaistetuissa regressiomalleissa käytetyistä liikunta-aktiivisuuden kynnyksistä [51]. Suomessakin liikuntamahdollisuuksien alueellisia eroja on korostettu yhtenä selityksenä liikuntatottumuksille [24,52].

Havaitut tulokset suosittavat, että liikuntapaikkojen suunnittelussa alhaisen sosioekonomisen taustan asuinalueet tulisi huomioida nykyistä paremmin, jolloin liikuntapaikkojen suunnittelu ei tapahtuisi paikkasokeasti. Tämä paikkatietoisuus tarkoittaa liikuntapaikkojen paikallista räätälöintiä väestörakenteen ja asuinympäristön ominaisuuksien mukaisesti. Yleisenä suunnitteluperiaatteena tätä ei ole vielä huomioitu liikuntapaikkojen suunnittelussa. Tämän vuoksi yhdyskuntasuunnittelulla ja kaavoituksella on merkittävä asema, kun tulevaisuudessa luodaan välittömiin asumisympäristöihin houkuttelevia arkiliikuntamahdollisuuksia erityisesti alemman sosioekonomisen taustan asuinalueille. Yleistä tahtoa tälle on, koska liikunnallisen elämäntyylin edistämistä pidetään yhteiskunnassa tärkeänä maan kansantalouden, kilpailukyvyn, kuntien elinvoimaisuuden, kansanterveyden sekä perheiden ja hyvinvoinnin kannalta [24].

Tämän tutkimuksen heikkoudet liittyvät käytettyjen aineistojen ominaisuuksiin. Tutkimustuloksia rajoittaa liikunta-aktiivisuuden mittaaminen kyselylomakkeella puhelinhaastattelussa sekä kyselylomakkeen validoinnin puuttuminen. Kuitenkin tämän kaltaisia kyselyjä on käytetty laajasti Suomessa [29,30], Pohjoismaissa [53] ja Skotlannissa [54], vaikka niiden avulla ei voida mitata liikunnan intensiteettiä, kestoa ja rasittavuutta tarkasti [29] ja lisäksi kysymysten on todettu olevan heikosti yhteydessä itse raportoituun energiankulutukseen [53]. Koska tässä tutkimuksessa käytetty liikunta-aktiivisuutta 
koskeva kysymys pohjautui itsearviointiin, ovat vastaajat myös voineet yli- tai aliarvioida omaa liikuntakäyttäytymistään, mikä on puolestaan voinut johtaa väärään luokitukseen fyysisessä aktiivisuudessa [53]. Mittaamisen luotettavuutta rajoittaa myös se, että vastaajien työhön liittyvää liikuntaa ei ole huomioitu kysymyksissä [54]. Lisäksi kysymys tarkastelee liikuntaa kapeasta näkökulmasta, sillä nykyään liikuntasuosituksissa kiinnitetään huomiota myös istumiseen ja korostetaan kestävyysliikunnan lisäksi lihaskuntoa kohentavaa liikuntaa. Samoin luotettavuuteen voi vaikuttaa myös se, että osallistuminen terveyskyselyihin on alhaisissa sosioekonomisissa väestöryhmissä vähäisempää kuin ylemmissä ryhmissä [55]. Vastaajakato koski tässä tutkimuksessa erityisesti pienituloisten vuokra-asujien väestöruuduilla asuvia miehiä, jotka olivat otoksessa aliedustettuina.

Käytettyjen paikkatietoaineistojen heikkoudet liittyvät tulosten yleistettävyyteen, mutta myös saavutettavuuden mittaamiseen pelkästään fyysisellä etäisyydellä. Jatkotutkimuksissa olisikin tarpeen tarkastella liikuntapaikkojen saavutettavuutta kaikilla saavutettavuuden ulottuvuuksilla erityisesti vähän liikkuvien miesten osalta. Tulosten hyödyntämisessä on lisäksi huomioitava, että saadut tulokset eivät ole suoraan yleistettävissä muualle, koska tulokset riippuvat alueellisen erilaistumisen määritelmästä. Menetelmällisesti alueellinen erilaistuminen voidaan luoda monella eri tavalla eikä ole myöskään olemassa yksiselitteistä määritystä siitä, mitä muuttujia tulisi käyttää alueellisen erilaistumisen kuvauksessa. Tuloksia yleistettäessä on myös muistettava alueelliset erityispiirteet. Kymenlaakso on selkeästi alueellisesti erilaistunut, minkä vuoksi alueelle muodostui fyysisesti inaktiivisten miesten kasautumia. Menetelmällistä lähestymistapaa voidaan kuitenkin suositella niille alueille, jotka ovat Kymenlaakson tavoin selkeästi erilaistuneet.

\section{KIRJOITTAJIEN KONTRIBUUTIOT}

Lehtonen on vastuussa tehdyistä analyyseistä sekä tekstin kirjoittamisesta. Kauronen on osallistunut artikkelin aineiston kokoamiseen ja tekstin kirjoittamiseen.

Lehtonen, 0., Kauronen, M.L. Accessibility of sport facilities for physically inactive men in urban areas of Kymenlaakso. Sosiaalilääketieteellinen aikakauslehti - Journal of Social Medicine 2017: 54: 327-344

Physical activity has increased during the last decades, but still part of the population is physically inactive, which means that they are not active enough to maintain their own health. Physical inactivity is linked to socio-economic differences: the higher socio-economic status is, the more likely an individual exercise in accordance with the recommendations of health authorities. Physical inactivity is mainly explained by individual factors, but also the living environment and its opportunities are found to be relevant to physical activity. The aim of this article is to examine the distribution of physically inactive men in urban areas in relation to the accessibility of sports facilities. We study how place-bounded are the opportunities for physical activities and analyze the variation of the accessibility of sports facilities be- tween residential areas with different socio-economic status. The article is based on a survey of self-reported physical activity and Grid database. Methodologically, the article utilizes accessibility analysis and spatial optimization. The results show that the socio-economic background of population grids is reflected on the physical activity of men. Physically inactive men accumulate in low-income population grids, where their relative incidence is the largest, but also where the population density is the highest. On average, the accessibility of sport facilities is poorer with physically inactive men than with the entire population.

Keywords: men, physical activity, regional differentation, accessibility, GIS, Kymenlaakso 
[1] Husu P, Paronen O, Suni J, ym. Suomalaisten fyysinen aktiivisuus ja kunto 2010. Terveyttä edistävän liikunnan nykytila ja muutokset. Helsinki: Opetus- ja kulttuuriministeriö; 2011.

[2] Conry MC, Morgan K, Curry P ym. The clustering of health behaviours in Ireland and their relationship with mental health, self-rated health and quality of life. BMC Public Health 2011;11:692. https://doi.org/10.1186/1471-2458-11-692

[3] Karvonen L, Nikander R. ja Piirainen A. Fyysisen aktiivisuuden merkitys elämänkulussa. Liikunta \& Tiede 53;1:68-74.

[4] Suni J, Husu P, Aittasalo M, ym. Liikunta on osa liikkumista - Paikallaanolon määritelmää täsmennetään parhaillaan. Liikunta \& Tiede 2014;51:30-32.

[5] Kelly P, Fitzsimons C ja Baker G. Should we reframe how we think about physical activity and sedentary behaviour measurement? Validity and reliability reconsidered. The International Journal of Behavioral Nutrition and Physical Activity 2016;13:32. https://doi.org/10.1186/s12966-016-0351-4

[6] Husu P, Suni J, Vähä-Ypyä H, ym. Objectively measured sedentary behavior and physical activity in a sample of Finnish adults: a crosssectional study. Public Health 2016;16:920. https://doi.org/10.1186/s12889-016-3591-y

[7] Sosiaali- ja terveysministeriö. Muutosta liikkeellä! - Valtakunnallinen yhteiset linjaukset terveyttä ja hyvinvointia edistävään liikuntaan 2020. STM Julkaisuja 2013;10.

[8] Borodulin K. Finriski-seurantatutkimus: Yhä harvempi suomalainen on täysin passiivinen vapaa-ajallaan. Liikunta \& Tiede 2014;51:4-10.

[9] Mäkinen T. Trends and explanations for socioeconomic differences in physical activity. Helsinki: National Institute for Health and Welfare; 2010.

[10] Borodulin K, Jousilahti P. Liikunta vapaaajalla, työssä ja työmatkalla 1972-2012 Tutkimuksesta tiiviisti 5. Helsinki: Terveyden ja hyvinvoinnin laitos; 2012.

[11] Husu P, Tokola K, Suni J, ym. Istuminen ja terveysliikuntasuositusten toteutuminen suomalaisilla aikuisilla vuonna 2013: ATHtutkimuksen tuloksia. Helsinki: Terveyden ja hyvinvoinnin laitos; 2014.

[12] Mäkinen T, Borodulin K, Laatikainen T ym. Twenty-five year socioeconomic trends in leisure-time and commuting physical activity among employed Finns. Scandinavian Journal of Medicine \& Science in Sports 2009;19:188-197. https://doi.org/10.1111/j.16000838.2007.00739.x

[13] Fone D, Dunstan F. Mental health, places and people: a multilevel analysis of economic inactivity and social deprivation. Health and Place 2006;12:332-344. https://doi.org/10.1016/j. healthplace.2005.02.002
[14] Giles-Corti B, Donovan R. Socioeconomic status differences in recreational physical activity levels and real and perceived access to a supportive physical environment. Prev. Med. 2002;35:601-611. https://doi.org/10.1006/pmed.2002.1115

[15] Greiner K, Li C, Kawachi I, ym. The relationships of social participation and community ratings to health and health behaviors in areas with high and low population density. Social Science \& Medicine 2004;59:2303-2312. https://doi.org/10.1016/j.socscimed.2004.03.023

[16] Rind E, Jones A. "I used to be as fit as a linnet" - Beliefs, attitudes, and environmental supportiveness for physical activity in former mining areas in the North-East of England. Social Science \& Medicine 2015;126:110-118. https://doi.org/10.1016/j.socscimed.2014.12.002

[17] Powell L, Slater S, Chaloupka F, ym. Availability of physical activity-related facilities and neighborhood demographic and socioeconomic characteristics: a national study. Am. J. Public Health 2006;96:1676-1680.

https://doi.org/10.2105/AJPH.2005.065573

[18] Bouchard C, Blair, S N, Haskell W L. Physical Activity and Health. Champaign: Human Kinetics; 2006.

[19] Purhonen S, Gronow J, Heikkilä R ym. Suomalainen maku - Kulttuuripääoma, kulutus ja elämäntyylien sosiaalinen eriytyminen. Helsinki: Gaudeamus; 2014.

[20] Lehtonen, O. 2007. Muuttoliike alueellisesti erilaistuneille asuinalueille Kouvolan seudulla vuonna 2005. Joensuun yliopisto. Pro Gradu tut $\neg$ kielma.

[21] Knight A, McNaught A. (edt.). Understanding Wellbeing: An Introduction for Students and Practitioners of Health and Social Care. Oxford: Lantern Publishing Ltd; 2011.

[22] Mittelmark MB, Wold B, Samdal O. The Ecology of Health Promotion. Teoksessa Samdal, Oddrun 2012. Ecological Perspective on Health Promotion: Systems, Settings and Social Processes. Bentham Science Publishers.

[23] LaPlaca V, McNaught A, Knight A. Discourse on wellbeing in research and practice. International Journal of Wellbeing 2013;3:116125. https://doi.org/10.5502/ijw.v3i1.7

[24] Mäki-Opas, T. Terveyssosiologinen näkökulma liikunnallisen elämäntavan polarisoitumiseen - valinnat vai mahdollisuudet. Yhteiskuntapolitiikka 2015 80;3:263-272.

[25] Bender A, Din A, Favarger P, Hoesli M, Laakso $\mathrm{J}$. An analysis of perceptions concerning the environmental quality of housing in Geneva. Urban Studies 1997;34:503-513. https://doi.org/10.1080/0042098976104

[26] Bauman AE, Reis RS, Sallis, JF, ym. Correlates of physical activity: why are some people 
physically active and others not? Lancet 2012;380:258-271.

https://doi.org/10.1016/S0140-6736(12)60735-1

[27] Borodulin K, Jallinoja P, Koivusalo $M$. Epäterveellinen ruokavalio, vähäinen liikunta ja polarisaatio - syyt, kustannukset ja ohjaustoimet. Valtioneuvoston selvitys- ja tutkimustoiminnan julkaisusara 24/2016. Helsinki: Valtioneuvoston kanslia; 2016.

[28] Pampel F, Kueger P, Denney J. Socioeconomic disparities in health behaviors. Annu Rev Sociol. 2010;36:349-370.

https://doi.org/10.1146/annurev. soc.012809.102529

[29] Borodulin K, Zimmer C, Sippola R, ym. Health behaviours as mediating pathways between socioeconomic status and body mass index. International Journal of Behavioural Medicine 2012;19:14-22.

https://doi.org/10.1007/s12529-010-9138-1

[30] Hu G, Jousilahti P, Borodulin K, ym. Occupational, commuting and leisure-time physical activity in relation to coronary heart disease among middle-aged Finnish men and women. Atherosclerosis 2007;94:490-497. https://doi.org/10.1016/j. atherosclerosis.2006.08.051

[31] Moseley M. Accessibility: the rural challenge. London: Methuen; 1979.

[32] Brabyn L, Sutton S. A population based assessment of the geographical accessibility of outdoor recreation opportunities in New Zealand. Applied Geography 2013;41:124-131. https://doi.org/10.1016/j.apgeog.2013.03.013

[33] Huotari T, Antikainen H, Rusanen J. Perusterveydenhuollon ympärivuorokautisten päivystyspisteiden saavutettavuus. Helsinki: Sosiaali- ja terveysministeriön raportteja ja muistioita; 2013.

[34] Kruger J, Carlson S, Kohl I. Fitness facilities for adults: differences in perceived access and usage. Am J Prev Med. 2007;32:500-505. https://doi.org/10.1016/j.amepre.2007.02.003

[35] Kamphuis C, van Lenthe F, Giskes K, ym. Perceived environmental determinants of physical activity and fruit and vegetable consumption among high and low socioeconomic groups in the Netherlands. Health Place. 2007;13:493-503. https://doi.org/10.1016/j. healthplace.2006.05.008

[36] Karusisi N, Thomas F, Méline J, ym. Spatial accessibility to specific sport facilities and corresponding sport practice: The RECORD Study. The International Journal of Behavioral Nutrition and Physical Activity 2013;10:48. https://doi.org/10.1186/1479-5868-10-48

[37] KKTT. Katsaus kymenlaaksolaisten terveyteen ja terveyskäyttäytymiseen. Maakunnallinen terveydenedistämisen yhteistyöverkosto.

Kotka: Kymenlaakson sairaanhoito- ja sosiaalipalvelujen kuntayhtymä; 2011.

[38] Kaikkonen R, Murto J, Pentala O, ym. Alueellisen terveys- ja hyvinvointitutkimuksen perustulokset 2010-2015. Helsinki: Terveyden ja hyvinvoinnin laitos; 2015.

[39] Koskinen S. Suomalaisten työ, työkyky ja terveys 2000-luvun alkaessa. Helsinki: Terveyden ja hyvinvoinnin laitos; 2010.

[40] Helldán A, Helakorpi S, Virtanen S, ym. Suomalaisen aikuisväestön terveyskäyttäytyminen ja terveys, kevät 2013. Helsinki: Terveyden ja hyvinvoinnin laitos; 2013.

[41] Suomi K, Sjöholm K, Matilainen P, ym. Liikuntapaikkapalvelut ja väestön tasa-arvo. Seurantatutkimus liikuntapaikkapalveluiden muutoksista 1998-2009. Jyväskylä: Jyväskylän yliopisto; 2012.

[42] Lehto E, Konttinen H, Jousilahti P, ym. The role of psychosocial factors in socioeconomic differences in physical activity: a populationbased study. Scandinavian Journal of Public Health 2013;41:553-559. https://doi.org/10.1177/1403494813481642

[43] Hoebel J, Finger J, Kuntz, B, ym. Socioeconomic differences in physical activity in the middleaged working population: The role of education, occupation, and income. Bundesgesundheitsblatt Gesundheitsforschung Gesundheitsschutz 2016;59:188-196. https://doi.org/10.1007/s00103-015-2278-3

[44] Milligan G, Cooper M. An examination of procedures for determining the number of clusters in a data set. Psychometrika 1985;50:159-179. https://doi.org/10.1007/BF02294245

[45] Odland J. Spatial Autocorrelation. Newbury Park: Sage; 1988.

[46] Anselin L. Local indicators of spatial association LISA. Geographical Analysis 1995;27:93-115. https://doi.org/10.1111/j.1538-4632.1995. tb00338.x

[47] Kwan M-P. Space-time and integral measures of individual accessibility: A comparative analysis using a point-based framework. Geographical analysis 1998;30:191-216. https://doi.org/10.1111/j.1538-4632.1998. tb00396.x

[48] Holl A. Twenty years of accessibility improvements. The case of the Spanish motorway building programme. Journal of Transport Geography 2007;15:286-297. https://doi.org/10.1016/j.jtrangeo.2006.09.003

[49] Liikennevirasto. Digiroad: tietolajien kuvaus. Helsinki; 2013.

[50] Manaugh K, El-Geneidy A M. Does distance matter? Exploring the links among values, motivations, home location, and satisfaction in walking trips. Transportation Research Part A: Policy and Practice 2013;50:198-208. https://doi.org/10.1016/j.tra.2013.01.044

[51] Lehtonen, O, Kallunki V, Kauronen M-L ym. Tutkimusosio - terveys ja alueellinen erilaistuminen. Kirjassa: Kauronen M-L. (toim.) Miesten terveyskäyttäytyminen Kymenlaaksossa. Kotka: Kymenlaakson ammattikorkeakoulu, 2016, 9-118. 
[52] Valkeinen H, Mäki Opas T, Prättälä R ym. Liikuntapaikkojen läheisyyden yhteys liikuntalajien harrastamiseen. Helsinki: Terveyden ja hyvinvoinnin laitos; 2014.

[53] Lagerros Y T, Bellocco R, Adami H O ym. Measures of physical activity and their correlates: the Swedish National March Cohort. European Journal of Epidemiology 2009;24:161-169. https://doi.org/10.1007/s10654-009-9327-x

[54] Strain T, Fitzsimons C, Foster C, ym. Agerelated comparisons by sex in the domains of aerobic physical activity for adults in Scotland. Preventive Medicine Reports 2016;3:90-97. https://doi.org/10.1016/j.pmedr.2015.12.013
[55] Harald K, Salomaa V, Jousilahti P, ym. Non participation and mortality in different socioeconomic groups: the FINRISK population surveys in 1972-92. Journal of Epidemiology and Community Health 2007;61:449-454. https://doi.org/10.1136/jech.2006.049908

\section{OLLI LEHTONEN}

FT, erikoistutkija

Luonnonvarakeskus,

Talous ja ybteiskunta

Marja-Leena Kauronen

Tt $T$, yliopettaja

Kaakkois-Suomen ammattikorkeakoulu, Sosiaali- ja terveysala

\section{LIITTEET}

Liite 1. Keskiarvot alueellisen erilaistumisluokituksen muodostaneista muuttujista luokittain (Lähde Tilastokeskus 2014).

\begin{tabular}{|l|l|l|l|l|}
\hline Muuttuja & Vanhempi väestö & Keskituloiset & Pienituloiset & Hyvätuloiset \\
\hline Asuttuja ruutuja (n) & 359 & 750 & 151 & 207 \\
\hline Miehiä (n) & 12342 & 16677 & 7740 & 4305 \\
\hline Miehiä (\%) & 30,1 & 40,6 & 18,8 & 10,5 \\
\hline Korkeasti koulutettujen osuus (\%) & 9,5 & 13,6 & 8,3 & 28,0 \\
\hline Perusasteen suorittaneiden osuus (\%) & 38,5 & 25,5 & 38,6 & 14,0 \\
\hline Asukkaiden keskitulot (€) & 22856,0 & 28374,9 & 19106,2 & 36270,1 \\
\hline Pienituloisten kuluttajien osuus (\%) & 20,3 & 13,2 & 34,3 & 10,6 \\
\hline Vuokra-asuntojen osuus (\%) & 26,9 & 6,8 & 67,3 & 4,6 \\
\hline Asuntojen keskipinta-ala (m $\left.{ }^{2}\right)$ & 69,8 & 93,9 & 60,1 & 120,3 \\
\hline Eläkeläisten osuus asukkaista (\%) & 38,3 & 23,7 & 28,0 & 11,7 \\
\hline Työttömien osuus (\%) työvoimasta & 16,4 & 9,1 & 27,5 & 5,6 \\
\hline
\end{tabular}

